\title{
BSPD Conference to explore children's rights
}

Children suffering from the blight of dental decay caused by processed foods over-laden with sugar need protecting, according to Professor Amandine Garde, the founding director of the Law \& Non-Communicable Diseases Research Unit at the University of Liverpool.

A leading expert on the role that the law can have on promoting better health, Professor Garde (pictured) is a speaker in the first session of the British Society of Paediatric Dentistry's (BSPD's) Conference on 5 October when she will explain why she advocates for a child rights-based approach to the prevention of non-communicable diseases.

Also on the panel dedicated to discussing policies for reducing sugar consumption are Dr Emma Boyland, an Experimental Psychologist based at the University of Liverpool, and Dr Alison Tedstone, Chief Nutritionist at Public Health England. The session will be chaired by Dr Clare Ledingham, who also chairs the conference hosted this year by BSPD's Merseyside branch.

Professor Garde will promote a rightsbased approach supporting populationwide preventive measures as the most likely to ensure that the UK government and others around the world comply with their obligation to protect the right to the enjoyment of the highest attainable standard of health and related children's rights.

In particular, she will argue that governments are legally accountable for their failure to protect children from the damage that excessive sugar consumption causes and will reflect on the regulatory tools that public health campaigners have at their disposal to increase the pressure on the government to promote better health, and therefore reduce health inequities and improve compliance with children's rights. She will frame the discussion in a post-Brexit context, highlighting that trade negotiations should bear in mind the imperative for governments to protect public health.

Other speakers lined up for the virtual 2021 conference by Scientific Chair Laura Gartshore include:

- Dr Charlotte Waite, the community dentist and Charlotte Waite, a social worker who will discuss Advocating for Vulnerable Children and their Oral Health

- Dr Aideen Naughton: Childhood adversity brain development and life course legacy

- Dr Hannah Barham Brown, a GP and disability campaigner: Issues with my tissues and contending with EhlersDanlos Syndrome

- Dr Lola Solebo, a Consultant Opthalmologist: Through the eyes of a child

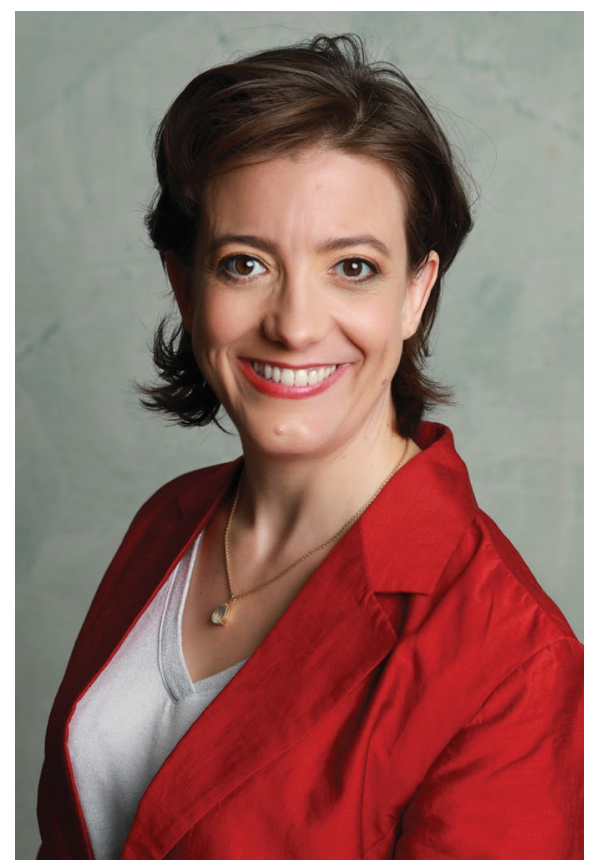

- Professor Julian Pine: How parents influence their children's language development

- Dr Sally Hibbert on transitional care.

The two-day virtual conference on 5 and 6 October will be preceded by the BSPD Teachers' Branch Study morning on 4 October. For more information and to register for the conference visit https://bspdconference.org.uk/ bspd-2021-scientific-programme/.

\section{Long-term approach to pay needed to keep NHS dentistry viable}

The British Dental Association (BDA) has said a long-term approach to pay is now required to keep NHS dentistry viable, following confirmation of a $3 \%$ pay award.

The pay award meets the recommendations made in the 49th report of the Review Body on Doctors' and Dentists' Remuneration (DDRB) in full, and marks the third consecutive aboveinflation increase following a decade of pay restraint, which saw real incomes for practitioners fall by over $35 \%$.

The pandemic has added to long-term pressures facing general dental services across the UK. Recent surveys indicate nearly half (47\%) of dentists in England are now likely to reduce their NHS commitment, should current restrictions remain in place, with the same proportion indicating they will seek early retirement or a change in career.

With inflation now at 2.5\%, the BDA has stressed an ongoing commitment to fair pay is required to guarantee the long-term sustainability of the service, alongside parallel action on a roadmap to ease pandemic restrictions and meaningful reform of the contractual systems NHS dentistry operates to. The discredited activity-based systems in operation across the UK have fuelled recruitment and retention problems and have proved unworkable since lockdown.

The announcement will see the 3\% uplift on pay backdated to April, with no staging. This will apply to community dentists in full, with a final uplift to contract values for general dental practitioners to be confirmed following consultations on expenses in the four UK nations. Consultants will see a 3\% uplift in basic pay (Specialty and Associate Specialists [SAS] and Juniors have separately agreed pay deals). The BDA has encouraged practice owners to engage with their associate dentists to discuss their contractual arrangements in light of the uplift.

BDA Deputy Chair Peter Crooks said: 'Both providers and performers need to see the benefit of this uplift. This has been a hard year for practices, but we look to owners to ensure this increase reaches their associates' 